\title{
Identifying New Product And Service Export Opportunities For South Africa Using A Decision Support Model
}

Wilma Viviers, North-West University, Potchefstroom campus, South Africa Ludo Cuyvers, University of Antwerp and North-West University, Potchefstroom campus, South Africa Ermie Steenkamp, North-West University, Potchefstroom campus, South Africa Sonja Grater, North-West University, Potchefstroom campus, South Africa Marianne Matthee, North-West University, Potchefstroom campus, South Africa Waldo Krugell, North-West University, Potchefstroom campus, South Africa

\begin{abstract}
In the face of slow economic growth and development, and the perennial problems of unemployment, poverty and inequality, the South African government and business community have long recognised the importance of growing and diversifying the country's tangible goods and services export sectors.
\end{abstract}

One of the challenges in designing and implementing effective export promotion strategies is identifying the right markets, given South Africa's ever-fluid skills, capacity and trading relationships. The Decision Support Model (DSM) is an export market selection tool that makes use of a sophisticated filtering process to sift through an extensive range of product-/service-and country-related data to reveal those product-/service-country combinations ('export opportunities') that are the most realistic and sustainable. The DSM, which has been applied for Belgium, Thailand and South Africa, not only brings greater precision to the export market selection process, but also unveils opportunities that may not have been contemplated before thus supporting the quest for export diversification.

This paper examines the role of the DSM for products and the DSM for services, respectively, and illustrates how, using the results from the application of these models, they herald the start of a new era in export market selection and promotion in South Africa.

Keywords: Export Opportunities; Export Promotion; Decision Support Model (DSM)

\section{INTRODUCTION}

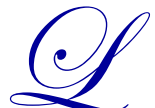

ike many developing countries, South Africa faces significant economic challenges, from tackling persistently high unemployment and widespread poverty, to improving the country's image as a trade and investment partner, and generating sustainable economic growth. Many government initiatives have been launched in recent years - at national, provincial and local level - to stimulate greater economic opportunities and put the country on a better economic footing. A key component in several of these initiatives is a stronger and more focused export drive.

Export promotion is important for creating employment opportunities, generating foreign exchange reserves, and improving the living standards of a country's citizens. However, whereas large numbers of possible export opportunities exist, relatively few have a realistic chance of being successfully exploited.

This paper first provides an overview of economic policies and initiatives introduced by the South African government in recent years, with special emphasis on their role in boosting the country's exports. 
Secondly, the paper evaluates South Africa's current export performance and traces the country's trade statistics since 2000. The firms responsible for generating the country's exports are profiled, highlighting the dynamic character of the export sector. This analysis reveals that the majority of exports produced by the firms in question are within the intensive margin (i.e. selling more of the same products to the same markets), which points to the need for export diversification and the role of South Africa's trade promotion organisations in steering firms towards the most promising export opportunities.

Thirdly, the paper discusses the importance of sound and forward-thinking export promotion, and demonstrates how an international market selection method, called the Decision Support Model (DSM), can be applied to identify the most promising realistic export opportunities for South Africa's products and services, against the backdrop of a rapidly changing international trading environment. This study updates, refines and extends - for South African conditions - the Decision Support Model (DSM) originally developed by Cuyvers et al. (1995) and Cuyvers (1996). A DSM for services was developed by Grater and Viviers (2012), and the results of the export opportunities relating to various services sectors are also analysed as an important component of the drive to diversify South Africa's exports.

The product-country and service-country combinations identified in this study can be used by South African trade promotion organisations to inform and focus their promotion activities. These export opportunities can guide exporters that want to expand their sales reach into foreign markets. Furthermore, they offer alternatives to current exporters that are facing saturation and/or declining growth in their traditional markets.

The research methodology and findings outlined in this paper are intended to contribute to one of the aims of the South African government, namely, to increase the country's exports and ultimately achieve higher economic growth rates, lower unemployment and less inequality in the country.

\section{RECENT SOUTH AFRICAN GOVERNMENT INITIATIVES}

The importance of increased industrialisation, as well as the need to enhance and diversify South Africa's exports, are highlighted in a number of national documents, e.g. the National Growth Path, the National Development Plan, the National Industrial Policy Framework (NIPF) (DTI, 2010a), the South African Trade Policy and Strategy Framework (TPSF) (DTI 2010b), as well as the Industrial Policy Action Plan (IPAP)(DTI, 2011).

The National Growth Path (NGP) and National Development Plan (NDP) are the two over-arching and complementary strategies that aim to guide government departments and businesses alike in their quest to achieve an inclusive, innovative and productive society.

The NGP emphasises the importance of the state in bringing about much-needed development in South Africa, as well as economic and trade policies that are designed to boost economic growth while also supporting labour-absorbing manufacturing. Furthermore, it states that South Africa should be focusing on the BRICS countries and regional partners for international trade and investment opportunities, and selecting foreign markets on the basis of South Africa's ability to competitively and sustainably supply such markets.

The NDP also has job creation as a core component, and subscribes to the idea of the state playing a developmental and transformative role. However, it asserts that the capacity of the state needs to be built up so that it can fulfil its mandate effectively. Export growth and greater competitiveness are two of the cornerstones of the NDP, along with the recognition that other emerging economies (including the rest of the BRICS grouping) are a valuable source of export and FDI opportunities for South Africa. A recurring theme in the NDP is that economic growth and development can be accelerated if there is greater efficiency in both the public and private sectors, value-added and innovative sectors are given priority, and business, labour and government cooperate in determining the best way forward.

South Africa's National Industrial Policy Framework (NIPF) is the government's broad approach to industrialisation and was adopted by the National Cabinet in 2007. The NIPF seeks to encourage value-added, labour-absorbing industrial protection, and diversify the economy away from its current over-reliance on traditional 
commodities and non-tradable services, thus creating the catalyst for employment growth (DTI, 2010a). Other features include building a knowledge economy and enhancing the country's productive capacity, especially among previously disadvantaged and marginalised communities. Key ingredients in this process include innovation, education and skills development, a sector-specific focus, and a trade policy framework that supports greater inroads being made into the African continent and South-South collaboration.

The Industrial Policy Action Plan (IPAP) was adopted by the National Cabinet in 2010 (DTI, 2011). Its latest revision, IPAP2, identifies priority sectors for industrialisation, and outlines associated actions and success factors. A major theme of IPAP2 is the need for South Africa to diversify its export mix, and focus on value-added manufactured and service exports that can help to address unemployment and poverty head on. The TPSF, in turn, which was released in 2010 and supports the objectives of South Africa's industrial policy, clarifies the country's trade initiatives at multilateral, regional and bilateral levels, and suggests various tariff adjustments with a view to boosting trade.

Given the knowledge and skills deficiencies that permeate the export sector in the country, the DTI's recently launched (in 2013) National Exporter Development Programme (NEDP) is particularly timeous. The NEDP is a multi-faceted initiative aimed at boosting exporter readiness through the identification of viable products and markets, as well as training, knowledge sharing, and support. Small businesses are the primary target of the development programme, which takes its broad direction from the NDP, NGP, NIPF and TPSF. According to the DTI, "the programme aims to build on existing activities and capacities at the DTI, provincial economic development departments, provincial trade and investment agencies, the Small Enterprise Development Agency (SEDA), and other international and local stakeholders to ensure the delivery of key interventions to emerging and experienced exporters" (Parsons, 2013).

Even the most well-informed and coherent trade policies and initiatives cannot on their own deliver on the challenges of diversifying the export mix, gaining greater market access, and seeing off the competition. Much is dependent on whether the business environment is conducive to the development and expansion of a viable export sector. This assumes, inter alia, that businesses have sufficient incentive to get involved in exporting, and can rely on ongoing and accessible information and practical assistance from both government and private sector trade specialists.

\section{EXPORTER DYNAMICS}

\subsection{South African Exports}

Since the onset of the new millennium but before the global financial crisis, South Africa experienced an average annual export growth rate of $14.32 \%$ (in nominal value terms). Since 2008 (through 2012), the growth rate averaged $6.37 \%$ (UnctadStat, 2013). Unfortunately, in volume terms, a similarly bleak picture has emerged. According to Parsons (2013), export volumes grew by only 3.9\% between 2000 and 2007, and since 2008, the growth rate has declined to $2 \%$.

For many years, South Africa's top export destinations were mainly the high-income countries, such as the United States, Germany, the United Kingdom and Japan. However, given the growing influence of the emerging markets and the slowdown in the United States and Europe in recent years, South Africa's trade alliances and patterns have been changing. China is now South Africa's largest single export destination, although Europe remains the country's biggest export region. Africa, though not without its challenges, is seen as a priority by South Africa's trade officials, as is the BRICS grouping, though time will tell whether BRICS will deliver economic benefits in addition to its obvious political benefits.

South Africa's export performance is extremely important to the country's overall economic wellbeing, contributing 29\% to the country's GDP in 2011 (World Bank, 2013). Despite appeals and efforts to build capacity in the manufacturing sector and increase the range of value-added exports, South Africa is still very reliant on commodities for its export earnings. Metals and mineral products, for example, account for at least $50 \%$ of the country's merchandise exports. Relatively little agricultural output finds its way to export markets. However, one 
shining star in terms of its ability to deliver large volumes of high-value manufactured exports is the automotive industry, which has benefited from a very focused government investment and export promotion campaign in recent years.

Among the many challenges that South Africa's exporters have to face is the reality of the country's declining global competitiveness, which is making it increasingly difficult to run successful operations and attract sustainable business. Though it is a very complex problem that requires a collective effort to fix, competitiveness needs to take centre stage in South Africa's export promotion efforts.

Taking an aggregate view of a country's export performance, however, encourages blunt policy interventions like high-level trade agreements, or incentives that benefit only specific industry interest groups. To achieve focus in the country's export drive, more needs to be known about the firms that export and their behaviour. The following sub-section puts South Africa's exporters under the microscope.

\subsection{South African Exporting Firms}

In 2012, the World Bank published a new database on exporting firms. The Exporter Dynamics Database contains customs data from 38 developing and 7 developed countries spanning the period 2001 to 2009 (Cebeci et al., 2012). This database provides information on different types of exporters, which illustrates the dynamics of exporting firms. Cebeci et al. (2012:15) offer the following definitions of firms included in the database:

- An exporter $r_{t}$ is any firm that exports in year $t$,

- $\quad$ an entrant $t_{\mathrm{t}}$ is a firm that does not export in year $\mathrm{t}-1$ but exports in year $\mathrm{t}$,

- $\quad$ an exiter ${ }_{t}$ is a firm that exports in year $\mathrm{t}-1$ but does not export in year $\mathrm{t}$,

- $\quad$ an incumbent $t_{t}$ is a firm that exports in both years $t-1$ and $t$

- $\quad$ a survivor ${ }_{t}$ is a firm that does not export in year $\mathrm{t}-1$ but exports in both years $\mathrm{t}$ and $\mathrm{t}+1$.

The point of departure in describing the dynamics of South African exporting firms is to consider their basic characteristics, i.e. arrive at a profile of the types of firms that get involved in exporting. Table 1 presents this information for the period 2003 to 2007, as this timespan coincides with the data used in the application of the DSM (see section 5). The number of exporters declined somewhat during the period, whereas the average export value per exporter increased. Furthermore, the number of new exporters decreased, but the number of firms no longer exporting also tapered off. This was also evident in the firm entry and exit rates. On average for the period, the firm survival rate was $47 \%$ (this shows that $53 \%$ of new entrants in a particular year did not export in the following year). The number of incumbents remained more or less steady over the period, and the same holds for the number of survivors. Moreover, the growth rate of the incumbent exporters over the 5 year period was $6 \%$ and that for survivors was $34 \%$. New entrants contributed very little (2\%) to the total export value.

Table 1: Basic Characteristics And Firm Dynamics In South Africa's Export Sector

\begin{tabular}{|l|c|c|c|c|c|c|}
\hline & $\mathbf{2 0 0 3}$ & $\mathbf{2 0 0 4}$ & $\mathbf{2 0 0 5}$ & $\mathbf{2 0 0 6}$ & $\mathbf{2 0 0 7}$ & Average \\
\hline Number of exporters & 22544 & 21661 & 20634 & 21251 & 21399 & 21498 \\
\hline Number of entrants & 7852 & 6936 & 5853 & 6114 & 5904 & 6532 \\
\hline Number of exiters & 8328 & 7819 & 6880 & 5497 & 5756 & 6856 \\
\hline Number of survivors & 3194 & 2906 & 2946 & 3026 & 2983 & 3011 \\
\hline Number of incumbents & 14692 & 14725 & 14781 & 15137 & 15495 & 14966 \\
\hline Firm entry rate & $35 \%$ & $32 \%$ & $28 \%$ & $29 \%$ & $28 \%$ & $30 \%$ \\
\hline Firm exit rate & $36 \%$ & $35 \%$ & $32 \%$ & $27 \%$ & $27 \%$ & $31 \%$ \\
\hline Firm survival rate & $41 \%$ & $42 \%$ & $50 \%$ & $49 \%$ & $51 \%$ & $47 \%$ \\
\hline Average export value per exporter (in SA rands) & 1299333 & 1712595 & 2075348 & 2272435 & 2706501 & 2013242 \\
\hline
\end{tabular}

Source: World Bank (2012)

The second aspect to consider when examining firm dynamics is the export growth rate over the period. More specifically, the goal is to determine whether the growth in total export value (19\% from 2003 to 2007) was the result of increases in the number of exporters or increases in the average size of established exporters. From the 
calculations it is evident that the growth of South Africa's exports was due to an increase in the average export value of existing exporters. A further decomposition of the period shows that the share of the top $1 \%$ of exporters in the total export value was $77 \%$, the share of the top 5\% of exporters in the total export value was $91 \%$, and the share of the top 25\% of exporters in the total export value was $99 \%$. This represents a high concentration of exports in the hands of a relatively small number of established firms. The rest export very little.

The World Bank (2012) provides more data to emphasise the level of concentration or diversification of export supply among South African firms. This is shown in Table 2. The large differences between the mean and median figures highlight the skewed composition of South African exporters. Over the time period considered, the average number of HS products per exporter increased by 4 ( 1 per year), but the median indicates that this number remained largely unchanged. Likewise, the number of destinations per exporter was more or less constant over the period.

Table 2: Export Concentration/Export Diversification In South Africa

\begin{tabular}{|l|c|c|c|c|c|c|}
\hline & $\mathbf{2 0 0 3}$ & $\mathbf{2 0 0 4}$ & $\mathbf{2 0 0 5}$ & $\mathbf{2 0 0 6}$ & $\mathbf{2 0 0 7}$ & Average \\
\hline In terms of HS products and destinations & & & & & & \\
\hline Number of HS6 products per exporter (mean ${ }^{1}$ ) & 11 & 12 & 13 & 14 & 15 & 13 \\
\hline Number of HS6 products per exporter (median ${ }^{2}$ ) & 3 & 3 & 3 & 3 & 3 & 3 \\
\hline Number of destinations per exporter (mean) & 3 & 3 & 4 & 4 & 4 & 4 \\
\hline Number of destinations per exporter (median) & 1 & 2 & 2 & 2 & 2 & 2 \\
\hline In terms of exporters & & & & & & \\
\hline Number of exporters per HS6 product (mean) & 57 & 60 & 63 & 70 & 74 & 65 \\
\hline Number of exporters per HS6 product (median) & 21 & 21 & 22 & 24 & 24 & 22 \\
\hline Number of exporters per destination (mean) & 346 & 331 & 339 & 342 & 349 & 341 \\
\hline Number of exporters per destination (median) & 50 & 47 & 50 & 50 & 52 & 50 \\
\hline
\end{tabular}

Source: World Bank (2012)

For the majority of countries, particularly those in the middle and high-income categories, most export growth takes place in the intensive margin, i.e. selling more of the same products to the same markets (Brenton \& Newfarmer, 2009). This is certainly true for South Africa as well (see Table 2). As is the case with other developing countries, it is critically important for South Africa to expand its exports in the extensive margin, which includes creating new trade flows through new product innovation and selling existing products to new markets. This diversification will reduce the country's vulnerability to external shocks. However, to achieve long-term, broadbased growth, a large cross-section of firms must be able to take advantage of the identified export opportunities (Reis \& Farole, 2012:5). Furthermore, it is important that these firms are able to overcome the many constraints that are threatening the firms' export operations in their early, start-up phase.

A study of African exporters by Cadot et al. (2011a) found that less than 20\% of new export initiatives survive the first year. Recent research on export survival suggests that exporting has an element of 'learning by doing' to it, and that exporting the same products to other markets, or exporting other products to the same markets strongly increases the chances of export survival. Furthermore, export survival appears to be affected by spill-overs. For example, Cadot et al. (2011b) found that the prospects of a firm surviving in exporting improve in line with the number of other firms also exporting the specific product to a specific market. These findings highlight the importance of knowledge spill-overs across exporters, and point to the potentially valuable role of trade promotion agencies in facilitating information exchange and collective action (Reis \& Farole, 2012:5).

In summary, the loss of competitiveness of South African exports at the aggregate level, along with the concentration of exports among relatively few firms in terms of products and destinations, calls into question the effectiveness of current policies to increase exports. There is a clear need for export diversification, a process that South African trade promotion organisations should be driving by marshalling firms' export efforts towards the most promising export opportunities. Given the low survival rate of new exporters and thus the difficulty of increasing exports from this group, the focus of this study is on increasing the exports of existing export products to new

\footnotetext{
${ }^{1}$ Average.

${ }^{2}$ A numerical value separating the higher half of the data from the lower half.
} 
markets/destinations, as well as bringing about diversification in the form of more service exports (see section 6). The need for focused export promotion will also be explored.

\section{THE NEED FOR EXPORT PROMOTION AND THE ROLE OF THE DECISION SUPPORT MODEL (DSM)}

The reality of South Africa's export performance is that there is limited diversification in terms of new destinations and new products. This is evidenced in South Africa's export growth being mainly driven by existing and experienced exporters servicing the same markets. Consequently, on-going research is needed to keep the government and private sector abreast of changing economic conditions and market dynamics, so that their various initiatives have a greater chance of bearing fruit.

With so much attention being paid to expanding South Africa's reach internationally, and diversifying and adding value to its exports, one of the most crucial steps in the export development process is identifying the right foreign markets. This can be a costly and complex exercise as so many variables come into play, and countries' fortunes are in a constant state of motion.

This study makes an important contribution to the national export effort by presenting the rationale for, and findings of, an ingenious instrument that takes the guesswork out of export market selection, enabling businesses across a wide range of industry sectors - to plan their export marketing activities with a high level of precision. This instrument is the Decision Support Model (DSM), which is designed to identify realistic export opportunities for individual companies or whole industry sectors. By using a powerful filtering system that processes large volumes of data, the DSM ultimately reveals those product-market combinations that show the greatest potential for the company or industry in question. It is primarily a strategic instrument aimed at assisting trade promotion organisations, e.g. the DTI, export councils and industry associations, in devising focused export promotion strategies for identified sectors and/or products. The DSM can be used by experienced and aspirant exporters alike, and is an invaluable aid in the initial, often expensive, stages of export market entry or expansion.

\section{THE DECISION SUPPORT MODEL FOR PRODUCTS}

\subsection{Introduction}

The Decision Support Model (DSM) is an analytical tool, incorporating a thorough screening process that facilitates systematic export market selection through the identification of realistic export opportunities for firms wanting to expand their sales reach into foreign markets. It also offers alternatives to exporters where they are facing saturation and/or declining growth in their traditional markets. The DSM methodology takes into consideration all possible worldwide product-country combinations and, using four filters, progressively eliminates less promising markets until those with the greatest prospects of success are revealed. The model therefore goes a long way towards ensuring that export marketing initiatives are executed in a focused and cost-effective way.

\subsection{The DSM methodology}

Filter 1 of the DSM assesses countries from the point of view of their political and commercial risk, and macroeconomic size and growth performance. Filter 2 assesses the market potential of the various product groups for the remaining countries, as determined by the size and growth of import demand. Filter 3 examines the accessibility of the remaining countries in terms of their different barriers to entry (including shipping time and cost, logistical efficiency, and tariffs and non-tariff barriers) and degree of market concentration (measured by the Herfindahl-Hirschman index). Filter 4 then categorises the final round of potential export markets according to South Africa's current export performance in these markets compared to the performance of the top six competitors in each market. A potential export value is also assigned to each identified product-market combination with a view to prioritising the shortlisted export opportunities.

Table 3 illustrates the categorisation of the potential export markets in filter 4 . In the columns of the table, South Africa's relative market share (compared to that of the top six competitors) is classified as small, 
intermediately small, intermediately high and high. In the rows of the table, the import size and growth of the identified markets are classified into five different combinations of markets showing above average short-term growth, long-term growth, and size of import demand (based on the analysis in filter 2).

Table 3: Final Categorisation Of Realistic Export Opportunities For South Africa

\begin{tabular}{|l|c|c|c|c|}
\hline & \multicolumn{3}{|c|}{ South Africa's relative market share } \\
\cline { 2 - 5 } & Small & $\begin{array}{c}\text { Intermediately } \\
\text { Small }\end{array}$ & $\begin{array}{c}\text { Intermediately } \\
\text { High }\end{array}$ & High \\
\hline Large product/market & Cell 1 & Cell 6 & Cell 11 & Cell 16 \\
\hline $\begin{array}{l}\text { Growing (short- \& long-term) } \\
\text { product/market }\end{array}$ & Cell 2 & Cell 7 & Cell 12 17 \\
\hline $\begin{array}{l}\text { Large product/market with short- } \\
\text { term growth }\end{array}$ & Cell 3 & Cell 8 & Cell 13 & Cell 18 \\
\hline $\begin{array}{l}\text { Large product/market with long- } \\
\text { term growth }\end{array}$ & Cell 4 & Cell 9 & Cell 14 & Cell 19 \\
\hline $\begin{array}{l}\text { Large product/market with short- } \\
\text { and long-term growth }\end{array}$ & Cell 5 & Cell 10 & Cell 15 & Cell 20 \\
\hline
\end{tabular}

Source: Cuyvers, Steenkamp and Viviers (2012)

Twenty different types of markets are distinguished in the DSM (depicted as cells in Table 3), which can assist South African exporters and trade promotion organisations to focus their export promotion efforts. Therefore, before conducting further investigations into a market identified as an export opportunity, they will know whether there is potential in terms of the size and/or growth of import demand, and the extent to which this potential has been exploited by South African exporters. For instance, if a product-country combination is classified in Cell 5, it means that the demand in that market is large and growing over both the short and long term, but South Africa has a relatively small share of that market.

\subsection{Results}

Given that South Africa's export growth is mainly driven by existing and experienced exporters selling to the same markets, the results discussed in this section will focus on new export opportunities for South Africa's exporters, with an emphasis on increasing the exports of existing export products to new markets/destinations.

In order to extract the results of the DSM for existing export products, only those export opportunities for products in which South Africa has a revealed comparative advantage (RCA) equal to or greater than $0.7^{3}$ are considered in this study. This follows Cuyvers et al.'s (2012) argument that export opportunities for which the exporting country has an RCA $\geq 0.7$ can be considered 'actual' export opportunities, since the country's comparative advantage is sufficiently large to warrant relatively rapid export success.

The actual export opportunities for South Africa's existing products, categorised according to the criteria in filter 4, are illustrated in Table 4.

${ }^{3} R C A j=\left(\frac{X_{S A, j}}{X_{\text {World }, j}}\right),\left(\frac{X_{S A, t o t}}{X_{\text {World,tot }}}\right)$

where $\mathrm{X}_{\mathrm{SA}, \mathrm{j}}$ is South Africa's exports of product $j, \mathrm{X}_{\mathrm{SA}, \text { tot }}$ is South Africa's total exports of all products, $\mathrm{X}_{\mathrm{World}, \mathrm{j}}$ is the world's exports of product $\mathrm{j}$ and $X_{\text {World,tot }}$ is total world exports of all products (Balassa, 1965; Krugell \& Matthee, 2009:461). 
Table 4: The Distribution Of The Potential Export Value ${ }^{4}$ Of South Africa's

Actual Export Opportunities According To Relative Market Position And Market Characteristics

\begin{tabular}{|c|c|c|c|c|c|}
\hline & $\begin{array}{l}\text { Market Share Of } \\
\text { South Africa } \\
\text { Relatively Small }\end{array}$ & $\begin{array}{c}\text { Market Share Of } \\
\text { South Africa } \\
\text { Intermediately Small }\end{array}$ & $\begin{array}{c}\text { Market Share Of } \\
\text { South Africa } \\
\text { Intermediately High }\end{array}$ & $\begin{array}{l}\text { Market Share Of } \\
\text { South Africa } \\
\text { Relatively High }\end{array}$ & Total \\
\hline Large Product/Market & $\begin{array}{l}\text { (Cell 1) } \\
5.61 \%\end{array}$ & $\begin{array}{l}\text { (Cell 6) } \\
3.10 \%\end{array}$ & $\begin{array}{l}\text { (Cell 11) } \\
9.94 \%\end{array}$ & $\begin{array}{c}\text { (Cell 16) } \\
3.06 \%\end{array}$ & $21.72 \%$ \\
\hline $\begin{array}{l}\text { Growing (Short- And } \\
\text { Long-Term) } \\
\text { Product/Market }\end{array}$ & $\begin{array}{l}(\text { Cell 2) } \\
(10.09 \%)\end{array}$ & $\begin{array}{l}\text { (Cell 7) } \\
(0.77 \%)\end{array}$ & $\begin{array}{l}(\text { Cell 12) } \\
0.507 \%\end{array}$ & $\begin{array}{l}(\text { Cell 17) } \\
0.70 \%\end{array}$ & $12.05 \%$ \\
\hline $\begin{array}{l}\text { Large Product/Market } \\
\text { With Short-Term } \\
\text { Growth }\end{array}$ & $\begin{array}{l}\text { (Cell 3) } \\
4.62 \%\end{array}$ & $\begin{array}{l}(\text { Cell 8) } \\
2.31 \%\end{array}$ & $\begin{array}{c}\text { (Cell 13) } \\
2.81 \%\end{array}$ & $\begin{array}{c}\text { (Cell 18) } \\
1.60 \%\end{array}$ & $11.34 \%$ \\
\hline $\begin{array}{l}\text { Large Product/Market } \\
\text { With Long-Term } \\
\text { Growth }\end{array}$ & $\begin{array}{l}(\text { Cell 4) } \\
4.08 \%\end{array}$ & $\begin{array}{l}\text { (Cell 9) } \\
2.97 \%\end{array}$ & $\begin{array}{l}\text { (Cell 14) } \\
3.15 \%\end{array}$ & $\begin{array}{c}\text { (Cell 19) } \\
1.68 \%\end{array}$ & $11.88 \%$ \\
\hline $\begin{array}{l}\text { Large Product/Market } \\
\text { With Short- And Long- } \\
\text { Term Growth }\end{array}$ & $\begin{array}{l}\text { (Cell 5) } \\
18.43 \%\end{array}$ & $\begin{array}{c}(\text { Cell 10) } \\
5.70 \%\end{array}$ & $\begin{array}{c}(\text { Cell 15) } \\
13.11 \%\end{array}$ & $\begin{array}{c}(\text { Cell 20) } \\
5.78 \%\end{array}$ & $43.01 \%$ \\
\hline Total & $42.83 \%$ & $14.84 \%$ & $29.51 \%$ & $12.82 \%$ & $100 \%$ \\
\hline
\end{tabular}

Source of data: Authors' own calculations based on DSM results

South Africa has a relatively small market share in the product-country combinations identified as export opportunities in Cell 1 to Cell 10. These can be considered new markets for South Africa's existing export products, and therefore the markets for export promotion organisations to focus on to increase export success when diversifying the country's exports.

Almost $60 \%$ of the potential export value of the actual export opportunities for South Africa is located in Cell 1 to Cell 10. Therefore, most of the export potential identified for South African products is in relatively new markets. This again underlines the need for export promotion organisations to focus on these export opportunities and for South Africa to diversify its export mix. The results of the DSM can contribute to these efforts, ensuring that the most attractive and accessible markets are targeted.

Table 5 provides a more detailed breakdown of the product-country combinations displaying the highest export potential for South Africa (based on the potential export value of each combination) if an extensive export strategy (i.e. selling existing export products to new markets) is followed.

\footnotetext{
${ }^{4}$ The most recent 2010 application of the DSM (see Steenkamp, 2011, and Steenkamp, Cuyvers \& Viviers, 2012) extended the DSM methodology described in section 5.2 by calculating a potential export value for each realistic export opportunity. This was done by dividing the total imports of product $j$ by country $i$ by the number of countries that supplies $80 \%$ of these imports. This estimation gives an indication of the size of the import demand for each product-country combination relative to other export opportunities.
} 
Table 5: Top 50 Actual Export Opportunities For South Africa In Cells 1-10 (Existing Export Products To New Markets) Ranked According To Potential Export Value

\begin{tabular}{|c|c|c|}
\hline Country & HS 6-Digit Product Code And Description & Filter 4 Cell Classification \\
\hline Canada & 870323 - Automobiles, spark ignition engine of $1500-3000 \mathrm{cc}$ & 5 \\
\hline United States & 840734 - Engines, spark-ignition reciprocating, over $1000 \mathrm{cc}$ & 8 \\
\hline China & 740311 - Copper cathodes and sections of cathodes unwrought & 10 \\
\hline United States & 740311 - Copper cathodes and sections of cathodes unwrought & 5 \\
\hline Germany & 740311 - Copper cathodes and sections of cathodes unwrought & 5 \\
\hline United States & 750210 - Nickel unwrought, not alloyed & 5 \\
\hline China & 870323 - Automobiles, spark ignition engine of $1500-3000 \mathrm{cc}$ & 2 \\
\hline Saudi Arabia & 870323 - Automobiles, spark ignition engine of $1500-3000 \mathrm{cc}$ & 2 \\
\hline China & 750210 - Nickel unwrought, not alloyed & 5 \\
\hline China & 854140 - Photosensitive/photovoltaic/LED semiconductor devices & 1 \\
\hline Germany & 870323 - Automobiles, spark ignition engine of $1500-3000 \mathrm{cc}$ & 1 \\
\hline Germany & 750210 - Nickel unwrought, not alloyed & 5 \\
\hline Australia & 870421 - Diesel powered trucks weighing $<5$ tonnes & 5 \\
\hline Brazil & 870323 - Automobiles, spark ignition engine of $1500-3000 \mathrm{cc}$ & 2 \\
\hline Germany & 842139 - Filtering or purifying machinery for gases nes & 9 \\
\hline Japan & 730890 - Structures and parts of structures, iron or steel, nes & 9 \\
\hline United Kingdom & 870323 - Automobiles, spark ignition engine of $1500-3000 \mathrm{cc}$ & 8 \\
\hline Netherlands & 284410 - Natural uranium, its compounds, mixtures & 5 \\
\hline India & 710239 - Diamonds (jewellery) worked but not mounted or set & 10 \\
\hline United States & 470329 - Chem wood pulp, soda/sulphate, non-conifer, bleached & 5 \\
\hline Turkey & 740311 - Copper cathodes and sections of cathodes unwrought & 5 \\
\hline United States & 740200 - Unrefined copper, copper anodes, electrolytic refining & 5 \\
\hline United States & 401120 - Pneumatic tyres new of rubber for buses or lorries & 6 \\
\hline Belgium & 870323 - Automobiles, spark ignition engine of $1500-3000 \mathrm{cc}$ & 8 \\
\hline United States & 870870 - Wheels including parts/accessories for motor vehicles & 6 \\
\hline United States & 851150 - Generators and alternators & 10 \\
\hline China & 470329 - Chem wood pulp, soda/sulphate, non-conifer, bleached & 10 \\
\hline United States & 840820 - Engines, diesel, for motor vehicles & 4 \\
\hline Thailand & 720839 - Flat rld prod/coils $>3 \mathrm{~mm}$ & 5 \\
\hline United States & 730890 - Structures and parts of structures, iron or steel, ne & 5 \\
\hline Italy & 870421 - Diesel powered trucks weighing $<5$ tonnes & 10 \\
\hline Belgium & 760110 - Aluminium unwrought, not alloyed & 5 \\
\hline India & 310530 - Diammonium phosphate, in packs $>10 \mathrm{~kg}$ & 4 \\
\hline Australia & $\begin{array}{l}293491 \text { - Aminorex, brotizolam, clotiazepam, cloxazolam, dextromoramide, } \\
\text { haloxazolam, ... }\end{array}$ & 5 \\
\hline Kazakhstan & 870323 - Automobiles, spark ignition engine of $1500-3000 \mathrm{cc}$ & 2 \\
\hline Italy & 720110 - Pig iron, non-alloy, <0.5\% phosphorus & 10 \\
\hline Country & HS 6-Digit Product Code And Description & Filter 4 Cell Classification \\
\hline United States & 842139 - Filtering or purifying machinery for gases nes & 10 \\
\hline China & 721049 - Flat rolled iron or non-alloy steel, coated with zinc, width $>600 \mathrm{~mm}$, nes & 1 \\
\hline Germany & 870322 - Automobiles, spark ignition engine of $1000-1500 \mathrm{cc}$ & 6 \\
\hline Malaysia & 740311 - Copper cathodes and sections of cathodes unwrought & 5 \\
\hline Saudi Arabia & 740311 - Copper cathodes and sections of cathodes unwrought & 10 \\
\hline China & 720918 - Flat rld prod/coils $>.5 \mathrm{~mm}$ & 3 \\
\hline United Kingdom & 710239 - Diamonds (jewellery) worked but not mounted or set & 6 \\
\hline Hong Kong & 854140 - Photosensitive/photovoltaic/LED semiconductor devices & 1 \\
\hline United States & 220210 - Beverage waters, sweetened or flavoured & 9 \\
\hline Germany & 470329 - Chem wood pulp, soda/sulphate, non-conifer, bleached & 5 \\
\hline China & 760200 - Waste or scrap, aluminium & 10 \\
\hline Greece & 740311 - Copper cathodes and sections of cathodes unwrought & 5 \\
\hline Spain & 870323 - Automobiles, spark ignition engine of $1500-3000 \mathrm{cc}$ & 10 \\
\hline Hong Kong & 711011 - Platinum unwrought or in powder form & 1 \\
\hline
\end{tabular}

Source of data: Authors' own calculations based on DSM results 
It is interesting to note that Brazil, India and China, which are part of the BRICS grouping, are among the countries which offer export diversification opportunities to South Africa. Over and above the developed countries, Saudi Arabia, Turkey, Thailand, Kazakhstan, Malaysia and Hong Kong also feature in the top 50. Furthermore, the products featuring most frequently within the top 50 are: $1500-3000 \mathrm{cc}$ automobiles; copper cathodes; unwrought, not alloyed nickel; and bleached chemical wood pulp.

The above results give an indication of the power of the DSM to deliver a cross-section of results given the exporting country's particular circumstances.

\section{THE DECISION SUPPORT MODEL FOR SERVICES}

\subsection{Introduction}

Although the IPAP2 document clearly emphasises the need for South Africa to give more attention to value-added products as well as the services sector, the current drive by the government is to diversify its product export base.

The trade in services, however, has become a dynamic economic activity as well as an important source of export diversification in developing countries. During 2000-2007, the global trade in services grew as quickly as the trade in goods, i.e. averaging 12\% per year (Reis \& Farole, 2012:5). Accordingly, it is equally important for South Africa to diversify and expand its exports in the services sector. Moreover, exports of goods and services often create synergetic effects. This is obvious considering e.g., the exports of goods with the provision of required financial services and transportation. Also other products-services combinations can offer better market prospects, such as e.g., exports of specialised equipment and training.

Services can perform two functions within the economy. Many services constitute inputs into production and therefore play a major role in the value-added composition of products, such as financial services, transportation and insurance. In addition, most services can be exported directly to foreign markets (Hoekman \& Mattoo, 2008). An increase in direct exports of services is very important for the overall growth in a country's trade. Brenton, Newfarmer and Walkenhorst (2009) assert that services can make a positive contribution to economic growth and export diversification by expanding the exports of existing services to existing markets, as well as developing new services exports or starting to export existing services to new markets.

South Africa's services sector or 'tertiary sector' on average amounted to $66 \%$ of total gross value added (GVA) between 2005 and 2010 (SARB, 2013), thus making a substantial contribution to the South African economy. Yet during the same period, the services sector's exports constituted on average only $18 \%$ of South Africa's total exports, and revealed a significant trade deficit each year (ITC, 2013). Exports of services during the period were largely concentrated in the travel (tourism) industry and the transportation sector, with much smaller proportions allocated to the remaining services sectors, such as business services, financial services, insurance, communications and construction (ITC, 2013). Clearly, there is a need for further diversification of the current services sector in South Africa, and for other services sectors to be stimulated.

One of the stumbling blocks to the expansion of the services export sector is that there are often vast differences in regulations between countries. Brenton, Newfarmer and Walkenhorst (2009) suggest that trade liberalisation and regulatory reforms should be complementary in order to create competitive services markets. They also stress the need for governments in developing countries to launch initiatives that build an appropriate domestic regulatory framework and assist local services firms to access new opportunities, both locally and abroad. This is one of the many reasons why the DSM for services was developed.

To cater for the very specific nature and conditions surrounding the supply of services, the DSM for products was adapted and applied using the available data for services in South Africa. The results reveal potential services export markets that have the highest demand as well as the lowest regulatory barriers. The South African government can use the information to formulate strategies to diversify and grow services exports, backed up by inmarket knowledge from services firms that are already exporting. 


\subsection{Filters used in the DSM for services}

Similar to the DSM for products, the DSM for services uses a progressive filtering process, although some of the filters had to be adapted to compensate for the limited availability of services data, and the specific nature of the services trade and its associated trade barriers.

Filter 1 applies the same methodology as that for the DSM for products, i.e. evaluates all countries' political and commercial risk, as well as macroeconomic size and growth, and eliminates those countries that either indicates very high levels of risk, or very low levels of macroeconomic performance (Grater \& Viviers, 2012).

Filter 2 applies the same methodology as that for the DSM for products, using the available import data for services per country on a sector level. The import demand and import growth for services in the short and long term are calculated in a similar way as that for the DSM for products. Those service-country combinations that reflect sufficient market size or growth over the short and long term, are then selected to go through to filter 3 (Grater \& Viviers, 2012).

The calculations of market concentration and accessibility, as applied in the DSM for products, cannot be used for the DSM for services since bilateral trade data for South African services are not available. Therefore, filters 3.1 and 3.2 had to be adapted to the available data for the services trade.

In this regard, filter 3.1 calculates market openness for each country on a services sector level, and market openness is then used as a proxy for the ease of entry into the market. Filter 3.2 evaluates the market accessibility of each services sector in each country by allocating a scale value to each country's GATS commitments under the WTO that are made on a sector level.

Filter 4 is not an elimination filter, but only takes the resulting list of service-country combinations that are able to pass through filters 1, 2 and 3, and creates the final list of export opportunities for services from South Africa. These results can be summarised by sector, by country or by region, and can also be combined in a cell structure similar to that of the DSM for products.

\subsection{Results}

Table 6 shows the number of export opportunities in various countries identified within South Africa's main services sectors revealed through the application of the DSM for services. (This table aggregates the results per sub-sector into main sectors). The table shows that even though there are significant export opportunities within the travel and transportation sectors (293 in total), there are also plenty of other opportunity areas, particularly in the 'other business services' sectors, as well as personal, cultural and recreational services, and computer and information services.

Table 6: Export Opportunities For South African Services Per Main Sector

\begin{tabular}{|c|l|c|}
\hline EBOPS code $^{\mathbf{5}}$ & \multicolumn{1}{|c|}{ Main Services Sector } & Number Of Opportunities \\
\hline 236 & Travel & 162 \\
\hline 205 & Transportation & 131 \\
\hline 268 & Other business services & 36 \\
\hline 287 & Personal, cultural and recreational services & 34 \\
\hline 262 & Computer and information services & 31 \\
\hline 253 & Insurance services & 28 \\
\hline 245 & Communications services & 22 \\
\hline 249 & Construction services & 16 \\
\hline 266 & Royalties and license fees & 10 \\
\hline 260 & Financial services & 2 \\
\hline 291 & Government services, not indicated elsewhere & \\
\hline
\end{tabular}

Source of data: Authors' own calculations based on DSM results

${ }^{5}$ Extended Balance of Payments for Services classification developed by the United Nations 
The results can also be classified according to a cell structure, as displayed in Table 7 below. The cell classification clusters the results according to the market size (as determined in filter 2), as well as the market openness and market accessibility (from filter 3.1 and 3.2). The rows in the table indicate the size of the import market and the columns indicate the level of market openness and access (Grater \& Viviers, 2012).

The ideal combinations of export opportunities are in the fourth column where the markets are very open for services and are easily accessible with low trade barriers. These opportunities would be the fastest for South African services sectors to act on, and government can assist firms to diversify to these markets within a relatively short time.

The first column, on the other hand, shows those markets that have very low openness and low market accessibility. This is where government should get involved in opening markets and lowering trade barriers through the negotiation of trade agreements under the GATS agreement.

Table 7: Cell Classification Of The Results Of The DSM For South African Services

\begin{tabular}{|c|c|c|c|c|}
\hline & $\begin{array}{c}\text { Low Openness \& Low } \\
\text { Market Access }\end{array}$ & $\begin{array}{c}\text { Low Openness \& } \\
\text { High Market Access }\end{array}$ & $\begin{array}{c}\text { High Openness \& } \\
\text { Low Market Access }\end{array}$ & $\begin{array}{c}\text { High Openness \& } \\
\text { High Market Access }\end{array}$ \\
\hline $\begin{array}{l}\text { Large Services } \\
\text { Market }\end{array}$ & $\begin{array}{c}\text { Cell 1 } \\
52(9 \%)\end{array}$ & $\begin{array}{c}\text { Cell } 6 \\
88(15 \%)\end{array}$ & $\begin{array}{l}\text { Cell } 11 \\
25(4 \%)\end{array}$ & $\begin{array}{l}\text { Cell } 16 \\
16(3 \%)\end{array}$ \\
\hline $\begin{array}{l}\text { Growing (Short-Term } \\
\text { And Long-Term) }\end{array}$ & $\begin{array}{c}\text { Cell 2 } \\
69(12 \%)\end{array}$ & $\begin{array}{c}\text { Cell } 7 \\
74(13 \%)\end{array}$ & $\begin{array}{l}\text { Cell 12 } \\
41(7 \%)\end{array}$ & $\begin{array}{l}\text { Cell 17 } \\
26(4 \%)\end{array}$ \\
\hline $\begin{array}{l}\text { Large Services } \\
\text { Market With Short- } \\
\text { Term Growth }\end{array}$ & $\begin{array}{c}\text { Cell } 3 \\
30(5 \%)\end{array}$ & $\begin{array}{c}\text { Cell } 8 \\
42(7 \%)\end{array}$ & $\begin{array}{l}\text { Cell } 13 \\
9(1 \%)\end{array}$ & $\begin{array}{l}\text { Cell } 18 \\
8(1 \%)\end{array}$ \\
\hline $\begin{array}{l}\text { Large Services } \\
\text { Market With Long- } \\
\text { Term Growth }\end{array}$ & $\begin{array}{l}\text { Cell } 4 \\
7(1 \%)\end{array}$ & $\begin{array}{c}\text { Cell } 9 \\
14(2 \%)\end{array}$ & $\begin{array}{l}\text { Cell 14 } \\
8(1 \%)\end{array}$ & $\begin{array}{l}\text { Cell } 19 \\
3(1 \%)\end{array}$ \\
\hline $\begin{array}{l}\text { Large Services } \\
\text { Market With Short- } \\
\text { Term And Long- } \\
\text { Term Growth }\end{array}$ & $\begin{array}{c}\text { Cell } 5 \\
31(5 \%)\end{array}$ & $\begin{array}{l}\text { Cell 10 } \\
16(3 \%)\end{array}$ & $\begin{array}{l}\text { Cell 15 } \\
7(1 \%)\end{array}$ & $\begin{array}{l}\text { Cell 20 } \\
12(2 \%)\end{array}$ \\
\hline Total & $189(33 \%)$ & $234(40 \%)$ & $90(16 \%)$ & $65(11 \%)$ \\
\hline
\end{tabular}

Source of data: Authors' own calculations based on DSM results

In the above table, there are 65 service-country combinations (Cells $16-20)$ in markets that are easily accessible and also either very large or growing in the short- and long-term. These are the results that the South African government should give focused attention to with a view to expanding the services export sector. By way of an example, Table 8 shows the results from Cell 16 where the services market is very large for the specific sector, and there are high levels of market openness and market access. The total import value of the country for the specific sector is also shown to give an indication of the size of the market. 
Table 8: Results From Cell 16 Of The DSM For South African Services

\begin{tabular}{|c|c|c|c|c|c|}
\hline Country & Region & Main Sector & Sub-Sector & $\begin{array}{l}\text { Sub-Sector Or } \\
\text { EBOPS Code }\end{array}$ & $\begin{array}{l}\text { Total Value Of } \\
\text { Imports 2007 } \\
\text { (US\$ Thousand) } \\
\end{array}$ \\
\hline South Korea & Asia & Transportation & Sea transport - freight & 208 & 12828300 \\
\hline Singapore & Asia & Transportation & 1.1.2 Sea transport - freight & 208 & 9117325 \\
\hline Germany & Europe & Transportation & 1.2.3 Air transport - other & 213 & 2053323 \\
\hline Netherlands & Europe & Transportation & 1.2.3 Air transport - other & 213 & 1900387 \\
\hline Germany & Europe & Transportation & 1.3.3 Other transport - other & 217 & 4032579 \\
\hline Germany & Europe & Transportation & $\begin{array}{l}1.9 \text { Other supporting and } \\
\text { auxiliary transport services }\end{array}$ & 232 & 4231464 \\
\hline Country & Region & Main Sector & Sub-Sector & $\begin{array}{l}\text { Sub-Sector Or } \\
\text { EBOPS Code }\end{array}$ & $\begin{array}{l}\text { Total Value Of } \\
\text { Imports } 2007 \\
\text { (US\$ Thousand) } \\
\end{array}$ \\
\hline Greece & Europe & Transportation & $\begin{array}{l}1.9 \text { Other supporting and } \\
\text { auxiliary transport services }\end{array}$ & 232 & 3410684 \\
\hline Azerbaijan & Asia & Construction & $\begin{array}{l}4.2 \text { Construction services - } \\
\text { construction in the compiling } \\
\text { economy }\end{array}$ & 251 & 1471110 \\
\hline Singapore & Asia & $\begin{array}{c}\text { Insurance } \\
\text { services }\end{array}$ & $\begin{array}{l}5.3 \text { Insurance services - other } \\
\text { direct insurance }\end{array}$ & 256 & 359432 \\
\hline Singapore & Asia & $\begin{array}{c}\text { Other business } \\
\text { services }\end{array}$ & 9.3.1.1 Legal services & 275 & 231661 \\
\hline Singapore & Asia & $\begin{array}{c}\text { Other business } \\
\text { services }\end{array}$ & $\begin{array}{l}\text { 9.3.1.2 Accounting, auditing, } \\
\text { book-keeping and tax } \\
\text { consulting services }\end{array}$ & 276 & 351067 \\
\hline Singapore & Asia & $\begin{array}{c}\text { Other business } \\
\text { services }\end{array}$ & $\begin{array}{l}\text { 9.3.1.3. Business and } \\
\text { management consultancy and } \\
\text { public relations services }\end{array}$ & 277 & 1851277 \\
\hline Ireland & Europe & $\begin{array}{c}\text { Other business } \\
\text { services }\end{array}$ & $\begin{array}{l}\text { 9.3.2 Advertising, market } \\
\text { research, and public opinion } \\
\text { polling }\end{array}$ & 278 & 4172436 \\
\hline Singapore & Asia & $\begin{array}{c}\text { Other business } \\
\text { services }\end{array}$ & $\begin{array}{l}\text { 9.3.3 Research and } \\
\text { development }\end{array}$ & 279 & 1410476 \\
\hline Singapore & Asia & $\begin{array}{c}\text { Other business } \\
\text { services }\end{array}$ & $\begin{array}{l}\text { 9.3.4 Architectural, engineering } \\
\text { and other technical services }\end{array}$ & 280 & 1471627 \\
\hline Ireland & Europe & $\begin{array}{c}\text { Other business } \\
\text { services }\end{array}$ & $\begin{array}{l}\text { 9.3.5.2 Other agricultural, } \\
\text { mining and on-site processing }\end{array}$ & 283 & 156998 \\
\hline
\end{tabular}

Source of data: Authors' own findings based on DSM results

From Table 8 it is clear that a variety of services show potential in this specific cell of the DSM results for services, particularly in Singapore, Germany and Ireland.

Like the DSM for products, the DSM for services reveals cross-cutting results that can be invaluable in the conceptualisation and planning phases of export promotion programmes for services.

\section{CONCLUSION: IMPLICATIONS OF THE DSM FOR THE DIVERSIFICATION AND SUSTAINABILITY OF SOUTH AFRICA'S EXPORT SECTOR}

With a country's sector being exposed to so much uncertainty these days, the construction of the Decision Support Models for products and services, respectively, is extremely significant. A notable strength of the DSM is that it reveals export opportunities that may not have been considered in the past, thereby supporting the quest to diversify into non-traditional export markets. Given South Africa's preoccupation with extending the country's reach into new territories, the DSM is set to play an increasingly important, strategic role in trade promotion circles. Furthermore, having a scientific market selection tool for the services export sector - which to date has lacked a formal vision or strategy - is a boon to those tasked with expanding and diversifying the country's services sector where so much potential lies. 


\section{AUTHOR INFORMATION}

Prof Wilma Viviers is the leader of the TRADE (Trade and development) research entity and NRF rated researcher at the North-West University (NWU), Potchefstroom campus. She holds a PhD in Economics and a Certificate in Export Practice, has an impressive array of publications, and is a leading authority in the fields of export promotion, competitive intelligence (CI) and economic development. Prof Viviers' passionate research interest in, and active contribution towards the realisation of, strategies to improve South Africa's trade performance and competitiveness, are acknowledged both locally and internationally. She has also received numerous awards in recognition of her ground-breaking research over the years. E-mail: wilma.viviers@nwu.ac.za (Contact author)

Prof Ludo Cuyvers is an extraordinary professor at the North-West University (Potchefstroom Campus) and emeritus professor at the University of Antwerp, Belgium, where he is Director of the Centre for ASEAN Studies. He has published widely in international peer-reviewed journals on international trade, export promotion, Asian economic development and the social impact of globalisation. Prof Cuyvers has authored several books and seminal papers on international economics and export promotion. He developed the Decision Support Model (DSM), which he originally applied to Belgium and Thailand's export situation, and thereafter with the help of Prof Viviers on the South African state. E-mail: ludo.cuyvers@uantwerpen.be

Dr Ermie Steenkamp is a senior lecturer in Economics and International Trade in the School of Economics and a researcher within the TRADE research entity at the North-West University (Potchefstroom Campus). She recently completed her $\mathrm{PhD}$ on identifying export opportunities for South Africa with special reference to Africa. Dr Steenkamp's research focuses mainly on international market selection, the measurement of market accessibility and export promotion in South Africa, as well as the analysis of export potential on a provincial or sectoral level. Other interests include measuring the developmental impact of increased exports, especially on unemployment. E-mail: ermie.steenkamp@nwu.ac.za

Dr Sonja Grater is a senior lecturer in the School of Economics at the North-West University (Potchefstroom Campus). She lectures undergraduate and postgraduate courses in the field of international trade. Dr Grater's research is focused on the trade in services and she has authored several publications in this field. As part of her research, Dr Grater developed the Decision Support Model (DSM) for the identification of South African export opportunities for services in particular. The results of the model can be used by government and businesses to develop and expand export markets for specific service sectors. E-mail: $\underline{\text { sonja.grater@nwu.ac.za }}$

Prof Marianne Matthee is an associate professor in the School of Economics at the North-West University (Potchefstroom Campus). She is also the School's programme leader for International Trade. Prof Matthee has authored and co-authored a number of national and international conference papers, working papers, research papers and journal articles. She teaches International Trade Relations to undergraduate and postgraduate students. Her current research interest is the internationalisation of firms in South Africa and Africa, with particular emphasis on the barriers that firms face in their internationalisation efforts and how their potential can be unlocked and access to foreign markets improved. E-mail: Marianne.matthee@nwu.ac.za

Prof Waldo Krugell is a professor, the director of the School of Economics and NRF-rated researcher at the NorthWest University (Potchefstroom Campus). He has numerous publications to his credit in the fields of geographical economics, foreign direct investment, as well as tourism economics and the link to development. Prof Krugell is one of the few economists in South Africa working on issues of geographical economics. In practice, this means local economic growth and development and the spatial implications of industrial policy. His current work specifically involves firm-level analysis of the importance of agglomeration for growth. E-mail: waldo.krugell@nwu.ac.za 


\section{REFERENCES}

1. Brenton, P. \& Newfarmer, R. (2009). Watching more than the Discovery Channel to diversify exports. In: R. Newfarmer, W. Shaw \& P. Walkenhorst (eds). Breaking into New Markets: Emerging lesson for export diversification. Washington, D.C: World Bank.

2. Brenton, P., Newfarmer, R. \& Walkenhorst, P. (2009). Avenues for Export Diversification: Issues for LowIncome Countries. MPRA Paper, No. 22758.

3. Cadot, O., Iacovone, L., Pierola, D. \& Rauch, F. (2011a). Success and failure of African exporters. Policy Research Working Paper series 5657, World Bank, Washington, D.C.

4. Cebece, T., Fernandes, A.M., Freund, C. \& Pierola, M.D. (2012). Exporter Dynamics Database. World Bank Policy Research Paper No. 6229.

5. Cadot, O., Carrérre, C. \& Strauss-Kahn, V. (2011b). Trade diversification: Drivers and impacts. In: Trade and Employment: From Myths to Facts, eds. Jansen, M, Peters, R \& Salazar-Xirinachs, J.M: 253-283, Geneva, ILO.

6. Cuyvers, L., De Pelsmacker, P., Rayp, G. \& Roozen, I.T.M. (1995). A decision support model for the planning and assessment of export promotion activities by government export promotion institutions: the Belgian case. International Journal of Research in Marketing, 12:173-186.

7. Cuyvers, L. (1996). Export opportunities: the case of Thailand: A Decision Support Model Approach. Journal of Euro-Asian Management, 2(2):71-97.

8. Cuyvers, W., Steenkamp, E., \& Viviers, W. (2012). The Methodology of the Decision Support Model (DSM). In: Cuyvers, L. \& Viviers, W. (eds). Export promotion: A Decision Support Model Approach. Stellenbosch: Sun Media Metro.

9. $\quad$ DTI see South Africa. Department of Trade and Industry.

10. Grater, S. \& Viviers, W. (2012). Adaptation and application of the DSM for services in South Africa; in Cuyvers, L. \& Viviers, W. (eds), Export promotion: a decision support model approach. Stellenbosch: Sun Media Metro.

11. Hoekman, B. (1996). Assessing the general agreement on trade in services. In Martin, W. \& Winters, L.A. The Uruguay Round and the developing countries. Cambridge: University Press, p. 88-124.

12. Hoekman, B. \& Mattoo, A. (2008). Services Trade and Growth. World Bank Policy Research Working Paper No. 4461, January.

13. International Trade Centre (ITC). (2013). Trade Map: existing and potential trade. Retrieved from: http://www.trademap.org/

14. Parsons, R. (2013). Zumanomics: The Road from Mangaung to 2030. Auckland Park: Jacana Media.

15. South Africa. Department of Trade and Industry. (2010a). The South African National Policy Framework. The DTI Campus, Pretoria.

16. South Africa. Department of Trade and Industry. (2010b). The South African Trade Policy and Strategy Framework. The DTI Campus, Pretoria.

17. South Africa. Department of Trade and Industry. (2011). Industrial Policy Action Plan (IPAP) The DTI Campus, Pretoria.

18. South African Reserve Bank (SARB). (2013). National accounts. Quarterly bulletin, 267, March. Retrieved from: http://www.resbank.co.za/Publications/QuarterlyBulletins.

19. UNCTADSTAT. (2013). UNCTAD statistics database. Retrieved from: http://unctadstat.unctad.org/ReportFolders/reportFolders.aspx

20. World Bank. (2012). Exporter Dynamics Database. Retrieved from: http://econ.worldbank.org/WBSITE/EXTERNAL/EXTDEC/EXTRESEARCH/EXTPROGRAMS/EXTTR ADERESEARCH/0,,contentMDK:23191417 pagePK:64168182 piPK:64168060 theSitePK:544849,00.ht $\underline{\mathrm{ml}}$

21. World Bank (2013). Retrieved from: http://data.worldbank.org/indicator/NE.EXP.GNFS.ZS 


\section{NOTES}

